\title{
Los factores de recursos humanos en la satisfacción del cliente en centros de llamadas de emergencia de empresas de distribución de energía
}

\section{Human resource factors on customer satisfaction in emergency call centers of power distribution companies}

\author{
Mahmood Bonyadi ${ }^{1 a}$, Hossein Bodaghi Khajeh Noubar ${ }^{2}$, Mojtaba Ramazani $^{3}$ \\ Islamic Azad University, Tabriz, $\operatorname{Iran}^{123}$ \\ Orcid ID: https://orcid.org/0000-0001-5599-1874 \\ Orcid ID: https://orcid.org/0000-0003-2083-50402 \\ Orcid ID: https://orcid.org/0000-0002-0700-9396 3
}

Recibido: 20 de febrero de 2020

Aceptado: 15 de agosto de 2020

\begin{abstract}
Resumen
El presente estudio tuvo como objetivo explorar los factores humanos asociados con los empleados que configuran la satisfacción del cliente en el campo de los centros de llamadas de emergencia de las empresas de distribución de energía. La literatura se revisó en una variedad de disciplinas diferentes, incluida la calidad del servicio, la gestión de recursos humanos y el marketing. La población estadística de este estudio está compuesta por todos los empleados de los centros de llamadas de emergencia de las empresas de distribución de energía, entre los cuales, según la tabla de Krejcie \& Morgan (1970), el tamaño mínimo de la muestra para este estudio es de 285 personas. El método de muestreo de este estudio fue un método aleatorio completo y los cuestionarios se distribuyeron entre la muestra seleccionada. Se utilizó el cuestionario de Dorna et al., (2018) para medir las variables. Los resultados del estudio muestran que los factores de la gestión de recursos humanos conducen al plan de trabajo, la satisfacción del empleado, la eficiencia del empleado, la satisfacción del cliente, la retención del empleado, la capacitación, el desempeño del empleado y, en última instancia, el desempeño organizacional. Los gerentes de los centros de llamadas de emergencia de las compañías de distribución de energía deben tener en cuenta que invertir en prácticas de recursos humanos ayuda a mejorar la satisfacción del cliente en los centros de llamadas de emergencia de las compañías de distribución de energía.
\end{abstract}

Palabras clave: Satisfacción del cliente, Centros de llamadas de emergencia de empresas de distribución de energía, factores de recursos humanos, ecuaciones estructurales.

\footnotetext{
Abstract

The present study aimed to explore the human factors associated with employees shaping customer satisfaction in the field of emergency call centers of power distribution companies. The literature was reviewed in a range of different disciplines including quality of service, human resource management and marketing. The statistical population of this study is consisted of all employees of emergency call centers of power distribution companies, among whom,
} 
according to Krejcie \& Morgan (1970) table, the minimum sample size for this study is 285 people. The sampling method of this study was complete random method and the questionnaires were distributed among the selected sample. Dorna et al. (2018) questionnaire was used to measure the variables. The study results show that the factors of human resource management lead to job plan, employee satisfaction, employee efficiency, customer satisfaction, employee retention, training, employee performance, and ultimately organizational performance. Managers of emergency call centers of power distribution companies should note that investing in human resource practices helps to improve customer satisfaction in emergency call centers of power distribution companies.

Keywords: Customer Satisfaction, Emergency Call Centers of Power Distribution Companies, Human Resource Factors, Structural Equations.

\section{Introduction}

Undoubtedly, the present world is the world of organizations, and the directors of these organizations are human beings; human beings who bring souls to the body of organizations, move them, and run them. Without human resources, organizations not only have no meaning, but also cannot be managed. Even as organizations become technologically advanced and transformed into a mass of hardware, still the role of human as a vital and strategic factor in survival of organizations is quite evident. Accordingly, human resources are considered to be the most valuable resource of today's organizations because they shape organizational decisions, solve organizational problems, and materialize efficiency. Increased efficiency of organizations and their increasing development requires growth and efficiency of employees as well as strengthening their motivation. Some management scholars have referred to motivation as the driving force or driving engine of human beings.

Among the resources that organizations have, many researchers have pointed to the importance of human resources in organizations. stated that "the most important asset of any organization enters the organization early in the morning and leaves it at the end of the working time" (Farsijani et al, 2011). According to Farsijani et al. (2011) and Shafiee-Nikabadi et al. (2011), employees of organizations and their management are essential elements in achieving competitive advantage for organizations. Given the increasing competition of organizations and environmental changes, organizations are looking for ways through which they can gain competitive advantage through their human resources. Meanwhile, human resource management can be mentioned. Human resource management leads to provision of more job responsibilities and challenges for employees. Human resource management enables employees to have required authority for decision-making in their work. Human resource management is directly related to motivational factors as well as employee satisfaction. Research has shown that human resource management leads to increased job satisfaction and motivation of employees and reduced employee absenteeism (Moghaddami \& Zare, 2008). On the other hand, emergency call centers of power distribution companies are one of the sensitive service centers 

which are based almost entirely on voice-to-voice encounter between employees and customers at the other side of the telephone line. In general, customers are less satisfied with the services they receive from call centers than the customers with face-to-face service interactions (Bennington et al., 2018). Academic researchers attribute this lack of interest in call centers to a variety of reasons such as cultural acceptance of technology (Bennington et al., 2018), general lack of experience in relation to technology, and problems experienced by older customers in the field of technology (Macarm, 2009). In addition, people often feel uneasy when dealing with automated answering machines; and during these calls they encounter moody staff and have to spend a long time to achieve their response and at the same time, they also receive poor services. Although the concept of call centers has been proposed as a communication marketing tool, but it is widely accepted that customer satisfaction is not usually associated with call center operations (Bennington et al., 2018).

In call centers, employees (call center operators) are the main connector between the organization and the customer. Employees often need to understand many different tasks simultaneously (Jasmand et al., 2012). They are expected to exhibit a reciprocal behavior that is capable of fulfilling managerial requirements such as maintaining quality of services including attention, understanding, accountability, and assurance, customer satisfaction (Sergant \& Frenkel, 2016), problem solving, handling large numbers of contact in a short time, and ensuring first call clarity, and participation in other activities such as comparative sales (Jasmand et al., 2012). All of these are often done in a stressful environment when dealing with clients having problems and with a low-cost approach to human resource practices (Powder \& Madopalie, 2019). This is a very challenging environment and loss of control when doing the activities causes fatigue and consequently staff displacement or absenteeism. It is worth noting that the key role of employees of emergency call centers of power distribution companies in customer relations has not been so much examined in academic research. These studies have directly examined customer satisfaction in emergency call centers of power distribution companies. Accordingly, the present study seeks to examine the employee-related paths that lead to customer satisfaction. In other words, we seek to examine types of employee-related factors and consider how these factors contribute to customer satisfaction in voice-to-voice service encounters in emergency call centers of power distribution companies.

The structure of this study is as follows. First, in reviewing the literature, we sought to identify and consider human (or employee-related) factors that influence or lead to customer satisfaction. The literature is summarized and categorized in (Table 1). The next section examines the key methods of examining the literature and formulation of central research questions, which are also guidelines for development of our research method. In the methodology section, the variables and the model estimation method are examined. In the final section, the results and the discussion related to the findings as well as recommendations are 


\section{Research background}

\section{Theoretical foundations}

Identification of human factors affecting customer satisfaction in emergency call centers of power distribution companies. The studies that were conducted to identify human factors that shape customer satisfaction in emergency call centers of power distribution companies were reviewed. First, the resources related to customer satisfaction and a wide range of factors affecting this are identified. Some of these factors are more primitive in the context of customer satisfaction and some others are more important, and there is a great deal of interaction between these factors that results in emergence of a set of complex and reciprocal interactions. Therefore, the resources are reviewed in order to find the relevant studies, in spite of lack of focus on customer satisfaction; and some of the factors identified in the first phase of resource search are also considered. As such, it is possible to further explore the surrounding factors and shaping of customer satisfaction in emergency call centers of power distribution companies, and the major factors can be examined and the interactions between environmental factors can be taken into account. Some studies in this area are listed in (Table 1). Resources directly dealing with customer satisfaction are grouped at the beginning of the table. The studies identified in the second part of the table are those that do not deal solely with customer satisfaction but are related to customer satisfaction issues. Resources from a diverse set of disciplines such as sources of key performance indicators, performance-based resources, quality of service resources, human resource management resources, and marketing resources were also examined. Therefore, we categorized the categories listed in (Table 1) as the primary sources of this study. In addition to (Table 1), the sub-section of resource review deals with each of the categories identified in the table and they are grouped according to similar instructions in the table.

\section{Management strategies}

According to sources, two important management approaches can be identified in emergency call centers of power distribution companies. On the one hand, the production line approach is focused on quality performance measures (such as handling a large number of calls in a short amount of time) without considering service quality, customer satisfaction, or employee well-being (Gilmour \& Moreland, 2000). In other words, according to this approach, the company homogeneously focuses its operations on sales volume and continuous monitoring and control of employees, with an emphasis on recording quantitative results. On the other hand, the customer orientation approach focuses on delivering quality of services by striving to create employee commitment and motivation through empowerment and organizational support 

(Gilmour \& Moreland, 2000). Although some studies report the use of both quantitative and qualitative criteria to measure call centers' performance (Bain et al., 2017), but there are considerable evidences suggesting that call center managers are still primarily focused on quantitative criteria (Gilmour \& Moreland, 2000). Achieving these criteria usually has a negative impact on employees' ability to provide high-quality services (Diane \& Rani, 2009). In this regard, it is necessary to consider whether an emergency call center of power distribution companies is regulated to achieve high-quality services or customer satisfaction or no. However, emergency call centers of power distribution companies are usually regarded as a functional tool to achieve greater customer satisfaction or as a CRM (Customer Relationship Management) tool to emphasize customer orientation approach. Under the customer orientation approach, the emergency call centers of power distribution companies move toward building stronger relationships with customers by supporting and helping them to meet their needs. The most appropriate option in order to achieve an optimum level between employee activities and employee efforts is co-operation agreement (whereby the user pays the phone call and participates in payment of part of the costs) and pay per call (in which the call centers divide these costs for each phone call and shares the costs with the main company) (Aksin et al, 2019). However, the topic of telephone call management strategies does not address the causes of service quality and customer satisfaction, but discusses the intended outcomes for emergency call centers of power distribution companies. Customer orientation approach is still considered to be the most appropriate managerial approach for organizations whose goal is to ensure quality of service or customer satisfaction (Carrie \& Lyaon, 2008); (Gilmour \& Moreland, 2000). 
Table 1

Classification of resources related to human factors in customer satisfaction in call centers

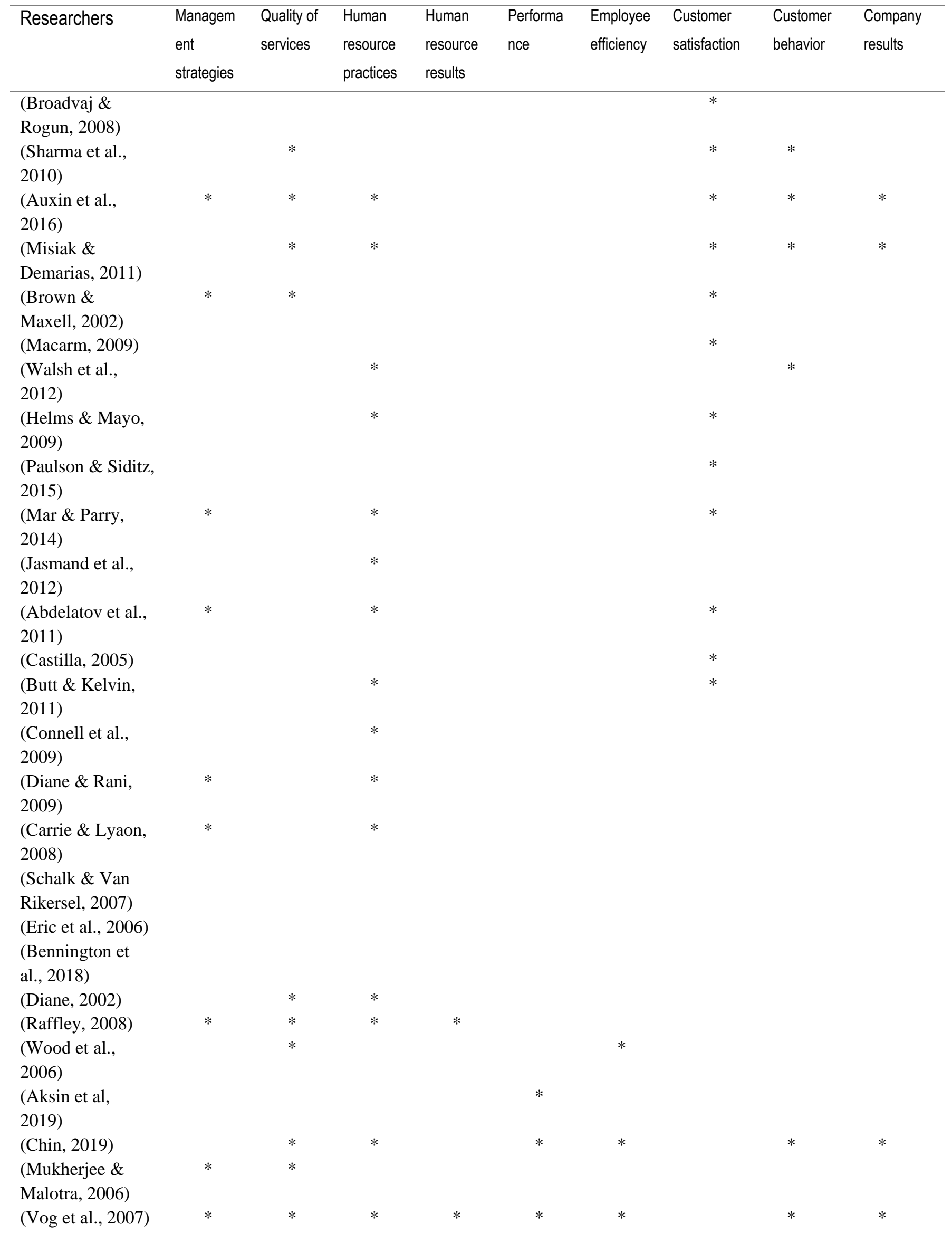




\section{Quality of services}

In general, previous studies indicate a direct cause-and-effect relationship between service quality and customer satisfaction (Siavallino \& Dahlgard, 2007); (Madren et al., 2007); (Sharma et al., 2010). However, it seems that customer's orientation or previous experience with the organization manages this relationship (Dorna et al., 2018) and (Sharma et al., 2010). In other words, regardless of the level of service quality, a negative ground inhibits customer satisfaction (Sharma et al., 2010). In addition, managers, employees, and customers often express different views on service quality (Gilmour \& Moreland, 2000). For example, from the customer's point of view, quality of services of emergency call centers of power distribution companies depends on the ability of the call center operator to adapt to each caller in terms of empathy, attention, responsiveness, and authority, and relationships such as attention, accountability, and understanding (Baradvaj \& Ruggerion, 2008). However, managers usually ignore customer orientation and preferential operational criteria such as response speed, number of handled calls, etc. to measure service quality (Liu, 2010).

A number of studies have examined the quality of services in call centers from the perspective of customer satisfaction versus customer dissatisfaction. According to this view, lack of factors that lead to customer satisfaction do not necessarily leads to customer dissatisfaction. For example, while customer satisfaction depends on the ability of employees to ensure clarity of the first call (Abdolatov et al., 2011) or the level of services (Chong et al., 2011), Other factors such as rude employees, slow or poor services are drivers of customer dissatisfaction. Similarly, when customers are satisfied with the service, they do not tend to refer to the service speed, but when they are not satisfied with the service, they will refer to the issue of service speed (Helms \& Mayo, 2009).

Although quality of services and the first clear call are largely dependent on the staff and how they perform their duties (Abdolatov et al., 2011), there may also be a relationship between the first telephone call and management strategies. In some cases, the tasks in emergency call centers of power distribution companies are designed in a way that responsibilities are distributed among the agents, such that employees often need to transfer calls to other departments. Consequently, customers frequently face with technology barriers, while in addition to having to pay for calls they also have to wait for the call. When the call is transferred to a correct agent, the customer will only be satisfied if he/she receives high-quality information and services (Garcia et al., 2012). Therefore, employees play a key role in actions that lead to customer satisfaction. In fact, in order to achieve customer satisfaction in call centers, we need to focus on quality of technology services and quality of human services (Brown \& Maxell, 2002); (Macarm, 2009); (Misiak \& Demarias, 2011) and move forward in 
line with customer expectations as well as in consistency with the predicted managerial strategies of companies. Therefore, achieving customer satisfaction is a complex process with multiple factors and mutual relations.

\section{Human resource practices}

As mentioned earlier, often stressful environments in call centers can lead to employee fatigue, displacement, or absenteeism in the workplace (Powder \& Madopalie, 2019) which are major internal problems associated with call centers (Pierciand Rich, 2009). In fact, it should be noted that employee behaviors and their outcomes are largely dependent on human resource practices. For example, some sources suggest that positive human resource practices improve employees' ability to provide high-quality services (Leith \& Diane, 2006) or that human resource practices based on training and evaluation of employees improve quality of services as well as customer satisfaction (Carrie \& Lyaon, 2008). However, it seems that in call centers, adoption of self-sacrificing human resource practices and measurement of employee performance based on "strict" quantitative measurements is a common issue. Subsequently, this results in provision of negative outcomes, such as high employee displacement or low commitment (Bain et al., 2017).

It has been widely accepted that adoption of customer-oriented approaches and improvement of job quality leads to resolving of the main causes of these negative outcomes (Butt \& Kelvin, 2011; Mar \& Parry, 2014; Wood et al., 2006). Job quality may be shaped by external factors such as economic or political status or by internal factors such as training programs, teamwork, employment of emotional staff (Powder \& Madopalie, 2019), or type of employment contract (Butt \& Kelvin, 2011; Schalk \& Van Rikersel, 2007; Macarm, 2009). For example, employing emotional and compassionate employees who are able to cope with stressful environments may improve phone call outcomes (Diane \& Rani, 2009) and reduce staff displacement and absenteeism (Powder \& Madopalie, 2019; Tossend, 2007). The concept of teamwork plays an important role in job design (Bharadwaj \& Roggeveen, 2008) by integrating dimensions such as group independence, solving the problems of decentralization, team caution, and collective responsibility. However, in the field of call service centers, it seems that teams are often understood as a tool to facilitate staff control and supervision (Schalk \& Van Rikersel, 2007). This may lead to a contradiction between quality and efficiency of services (Raz \& Blank, 2007). There are other concepts related to job quality and employee well-being in call centers, including physical environment and company support (McGuire \& McLaren, 2009), which in turn may contribute to achieving employee commitment (Butt \& Kelvin, 2011). In summary, positive human resource practices are important in terms of hiring, training, developing work team, ensuring corporate support and desirable physical environment, reducing job problems, absenteeism or displacement in the workplace, and increasing commitment among employees. 


\section{Human resource outcomes}

This section considers employee-based outcomes in implementation of specific human resource practices in emergency call centers of power distribution companies. In other words, we examine the consequences of human resource practices in terms of factors such as stress, job satisfaction, and absenteeism in workplace. Although employee satisfaction is a determining factor in customer satisfaction (as suggested by profit chain model) and quality of services, but it seems that in emergency call centers of power distribution companies, this relation is unilateral in both cases. On the other hand, sources suggest that even if employee satisfaction leads to high-quality services, but the reverse is not true. In other words, in voiceto-voice calls, most SERVQUAL dimensions appear to be negatively correlated with employee satisfaction, which is mainly due to management requirements to ensure SERVQUAL criteria that are considered as problems by employees and cause emotional dissatisfaction (Madren et al., 2007).

On the other hand, very few studies have examined the direct relationship between customer satisfaction and employee satisfaction in call center environments. According to the studies by Dhaka (2019), this relationship is mutual and complex. For example, it should be noted that in addition to employee satisfaction that leads to customer satisfaction, customer feedback (in terms of cognition or abuse) can lead to employee satisfaction, dissatisfaction, or emotional disturbance (Vog et al., 2007). For example, when employees deal with difficult or problematic customers, the negative customer feedback also affects employees leading to staff strictness or inability to perform their duties. Conversely, customer appreciation can lead to employee satisfaction. Therefore, the relationship between customer satisfaction and employee satisfaction is reciprocal in nature and, depending on the type of interaction the satisfaction may be obtained by both parties or by each of them. In addition, in voice-to-voice calls, this relationship can be influenced by external factors such as customer attitudes toward the company (Sharma et al., 2010) or employees' commitment to the organization. Thus, regarding customers or employees who have negative attitudes, a negative relationship can be observed between both parties that subsequently leads to customer dissatisfaction (Helms \& Mayo, 2009), or employee dissatisfaction. Outcomes of other employees can be considered in terms of whether employees are willing to stay in the company or no. In general, employee satisfaction can increase employee retention in the company. Naturally, most employees tend to stay in their jobs at emergency call centers of power distribution companies, and continue to stay in the company by obtaining greater knowledge and awareness over time (Powder \& Madopalie, 2019). 


\section{Employee efficiency}

In a number of studies examining customer satisfaction in emergency call centers of power distribution companies, researchers have mainly focused on key performance indicators (KPIs) that include: service level (calls answered at a specific time), average response speed, average waiting time, average non-response rate, percentage of first clear call, schedule adherence, average call time, average calls after working time, average employee displacement, percentage of blocked calls, the time before waiting, and total calls. However, most of these indices are derived from the SERVQUAL model and are well regarded as the criteria for internal service quality of calls. These factors can be categorized as below: employee behavior (displacement rate, program dependency), employee performance (service level, average response speed), and technology performance (average response time, non-response rate), which can actually be considered as part of quality of service.

\section{Customer satisfaction}

One of the most important evolutions in performance improvement in the last decade of the twentieth century was the issue of recognition of measurement of customer satisfaction as one of the main elements and requirements of management systems in business firms and entities. The great effort that is being made today by researchers, experts, and managers of business organizations in order to improve performance management tools and expand customer-oriented attitude shows that customer satisfaction is now one of the most important factors in determining success of organizations in business and profitability. Therefore, establishment and implementation of customer satisfaction measurement and monitoring systems, as the most important indicator in performance improvement, is considered one of the essential needs of today's organizations. However, it can never be overlooked that the main drivers for business and service organizations such as banks which are looking for major improvements in their development path are customers of that organization. In other words, no business can survive without customers. Therefore, it is so vital for every business organization to have a framework for understanding, analyzing, and evaluating its customer satisfaction status (Ziviar et al., 2012). Customers are individuals or processes that consume or need and benefit from the outcomes of a performance. As every performance in an organization certainly has a purpose, so it has customers, too. Customer-oriented is considered as an important factor in success of organizations. Customer satisfaction is one of the important theoretical and empirical issues for most marketers and marketing researchers. Customer satisfaction can be considered as the essence of success in today's competitive world of business. Therefore, the importance of customer satisfaction and customer retention and strategy formulation for customer-oriented and market-oriented companies cannot be underestimated. Thus, customer 
satisfaction at a growing rate has attracted the attention of companies. Various concepts of customer satisfaction have been introduced so far. In the past, it was enough to define the term customer as someone who purchases the company's product or service unit products. But this traditional definition is no longer accepted by all today. The new definition is that customer is someone that organizations and companies are willing to influence his/her behavior through the values they create (Ziviar et al., 2012).

\section{Review of literature}

Although review of literature considers a wide range of cause-and-effect relationships that begin with management strategies and human resource practices and end with customer outcomes, but it should be noted that cause-and-effect relationships are not completely clear. In this regard, further examination of some of the pivotal and environmental relationships is of great importance. This analysis may be facilitated by identifying and analyzing classical approaches that integrate all of these variables' groups, especially those that predict firm performance. These models include Lian technique, Balanced Scorecard, Six Sigma, and service-profit chain model. However, most of these models require a qualitative approach (Lian technique, Six Sigma, Balanced Scorecard), while our dataset is quantitative. Many of these models were originally designed for manufacturing industry, but they have also been used for different service industries including call centers.

A recent study shows that service-profit chain model is suitable for analyzing emergency call centers of power distribution companies at an international level. Following this example, we tested the service-profit chain model with some datasets. However, this model is not appropriate, and therefore we do not present it here. These results suggest that we should consider similar variables and take into account the possibility of different orientations in the relationships among variables in the original model that are incompatible with the data. Therefore, the researchers decided to take an exploratory approach to service-profit chain model as the baseline model to test the nature of the relationships between variables. Indeed, serviceprofit chain (SPC) model requires a quantitative approach, and although specifically designed for service industry, but academic researches focus mainly on face to face encounter, while applicability of this model to the specific area of voice-to-voice encounter is also important.

\section{Performance}

In today's competitive world where efficiency has increased in all areas, only organizations can remain in this turbulent world that make the best use of their resources and have the most efficiency. One of the important organizational resources is human resource. Performance evaluation systems lack required function in improving labor efficiency. Thus, the need to shift from such systems to the new performance management systems is increasingly felt. In recent years, performance management has been considered as one of the strategies for 
development and updating human resources and thus improving labor efficiency. Efficiency in general is the criterion to measure that how effective and efficient has been the use of resources as inputs to generate outputs needed in the society in the long run. If efficiency in its simplest form is considered as the ratio of outputs to inputs or the same productivity or outcome, obviously the lower the inputs, the higher will be the efficiency or productivity. This goal can be achieved in three ways:

- Reducing the amount of inputs and obtaining the same amount of outputs given the increased efficiency and improved system performance.

- Increasing the output amount by taking advantage of increased efficiency and improved system performance and the same previous amount of inputs.

- Simultaneous increase of output amount by taking advantage of increased efficiency and improved system performance as well as reducing the amount of inputs.

The workforce is considered the most important input in production of goods and services. Labor efficiency is derived by dividing the value added by average number of employees (or person/hour of work during a financial year). This indicator shows how much value added has been generated by each working human force in average. The criterion for measuring success of any organization is the amount of desirability of its employees' performance. Therefore, in order to measure success of organizations, there is need for progressive human resource systems that can increase efficiency of the whole system by providing appropriate solutions and creating the required coordination among the goals of the organization and goals of employees, and help the organization in achieving its goals and moving forward as much as possible (Seyyedi \& Akbari, 2009).

In order to make the best use of human resource factor, the necessary training needs to be formulated, and coordination and empathy should be created among employees, and their goals need to be aligned with the goals of the organization. Performance management by creating a collaborative environment and communicating the organizational goals to employees and ways to achieve them, as well as conducting employee evaluation and guidance sessions, and also by utilizing performance-based payment systems, aligns employee and organizational goals and increases workforce efficiency. In such a system, people feel more attached to the organization. Satisfactory performance of tasks by employees enhances overall performance of the organization. Therefore, a mutual commitment is created between employees and the organization that its result is nothing but improved performance, efficiency, and productivity of the organization. A kind of coordination is created between employee goals and organizational goals that the more employees strive to achieve organizational goals, the more their own goals, which are a mixture of compensatory rewards and more respect, are fulfilled, and on the other hand, the organization also by its increased efficiency can better earn money 
in the competitive environment and provide better compensatory rewards and facilities to its human force. Performance evaluation is considered an important task of human resource management in facilitating organizational effectiveness. Much attention has been paid to the role of performance evaluation in recent years. According to experts, an effective performance evaluation system can provide many benefits to organizations and their employees. Seyyedi \& Akbari (2009) stated that performance evaluation system a) provides a specific performance feedback to improve employee performance, b) determines employee training requirements, c) provides and facilitates the ground for employee development, d) establishes a close relation between personnel outcome and performance, and e) increases employee motivation and efficiency. Roberts \& Pavlak (1996) also believe that performance evaluation is used for a variety of supervisory and development purposes, including a) evaluation of individual performance based on organizational needs, b) prediction of feedback to employees in order to correct or strengthen their behavior, and c) providing rewards and job promotions for people.

However, many common human resource and management systems today do not seem to be appropriate and old models are considered inefficient. During the last decade, many organizations have found that in practice they lack a performance evaluation system through which they can transfer their priorities and goals to employees and pursue their improvement. Human being is sensitive due to the wide range of cognitive domains and use of various tools such as feeling, observation, perception, experience, and ability to belong and think in different subjects, especially in evaluating and interpreting the behavior and performance of employees, and all these factors influence how managers can achieve effective performance evaluation (Roberts \& Pavlak, 1996).

\section{Materials and methods}

\section{Research model}

(Figure 1) shows the conceptual model of the present study in which the relationships between various variables that ultimately influence the action and interaction between human resource factors and customer satisfaction are shown:

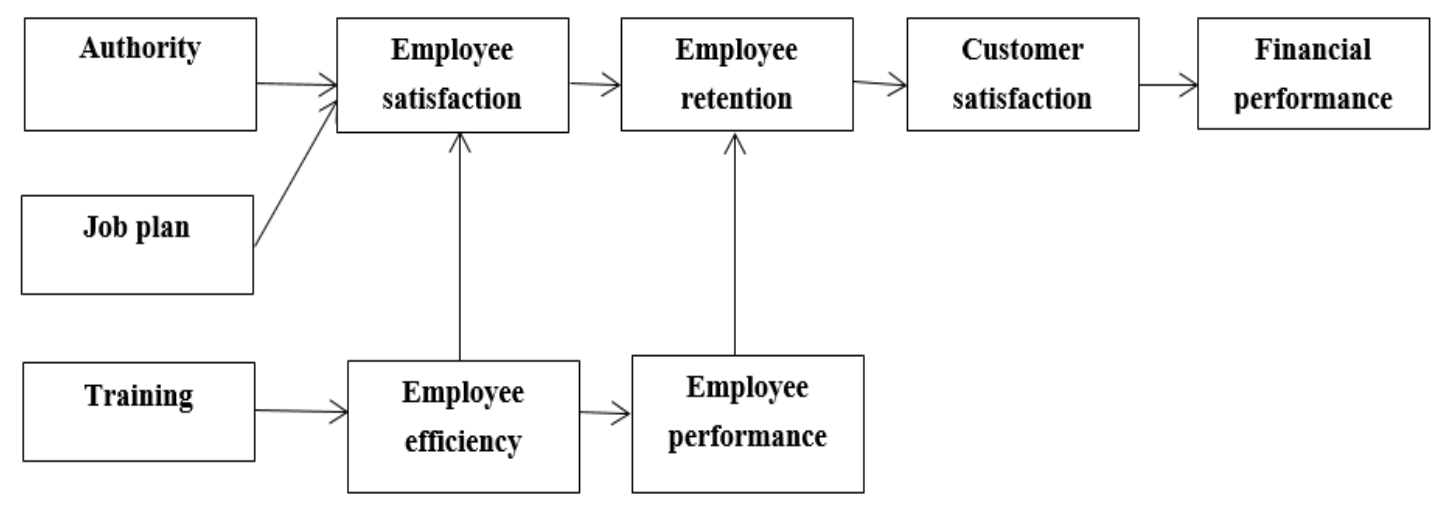


Figure 1. Conceptual model of research

\section{Research variables}

In order to measure various elements related to human factors considered in review of literature, taking into account the limitations associated with the use of secondary datasets, the following measures are used to examine human factors that shape customer satisfaction in emergency call centers of power distribution companies.

\section{Job plan (quality of services)}

This structure is made up of various elements of human resource management practices in companies. In the present study, these items were measured using job characteristics that are specifically related to quality of work of emergency call centers of power distribution companies; and, as explained in review of literature, it is focused on staff caution and their job design (Wood et al., 2006). Therefore, three factors are applied as follows:

1. Authority is modeled as a reflective factor and is measured by three indicators: the extent of employees' authority in performing their duties, authority regarding use of working methods, and authority related to job speed (all these are shown on 5-point Likert scale).

2. Job plan is modeled as a constructive factor and is measured by the percentage of staff doing autonomous tasks or semi-automated teams and the percentage of staff with flexible working arrangements.

3. Training is emphasized as one of the key human resource approaches in review of literature and is considered as a determinant factor of customer satisfaction in emergency call centers of power distribution companies. Training is a reflective structure that is measured by two indicators: formal training for main staff with interpersonal or team skills and the number of formal training methods received each year by main experienced staff.

To measure these, the questionnaire designed by Schalk \& Van Rikersel (2007) was used which examined all these on a 5-point Likert scale with 10 items.

\section{Employee satisfaction}

In order to measure this key dimension of human factor in terms of how it reacts to the policies applied by the company, the two following key indicators were considered:

Since this study is an organization-level survey, we therefore followed the usual method of replacing individual criterion of employee satisfaction by measuring proxy at organizational level. Erigo \& Pagani (2008) suggested that employee satisfaction may be considered as any type of employee tool. In this regard, authority is one of these measures. Indeed, in their metaanalysis, found a significant negative relationship between authority and job satisfaction, and this relationship is more particular in the area of service-profit chain studies. Harley \& Stalemy 
(2007) found that right job turnover is considered as a good criterion of employee satisfaction in determining the relationship with job satisfaction. Then, these findings moved the researchers toward using replacement rather than satisfaction as the criterion existing in organizations against the significant costs involved in collecting job satisfaction data. Following these recommendations, the variables used as indicators of employee satisfaction in this study are as follows:

1. Authority (percentage of absent employees on normal business days) and job turnover (percentage of employees who left the company in one year) both became positive indicators. Employee satisfaction structure was modeled as a reflective factor.

2. Employee retention: Following the studies by Harley \& Stalemy (2007), this structure was measured by the following two items: the usual right of main employees and the percentage of main employees with a right of more than 5 years. These items consider a reflective structure. To measure these, the questionnaire designed by Dorna et al. (2018) which included 7 questions was considered.

\section{Employee efficiency}

This factor is measured by two common indicators of efficiency of employees in emergency call centers of power distribution companies: the percentage of calls answered at a specific time (Harley \& Stalemy, 2007) and the number of calls answered by the main employees in a day. This factor was modeled as a constructive structure and was collected by asking from the considered centers.

\section{Employee performance}

This is a reflective structure that is measured by a single index, namely, the percentage of obtained performance. This indicator was obtained by asking from managers of emergency call centers of power distribution companies about measuring overall performance of their employees. This is a broader and more accurate criterion than employee efficiency which is similar to measuring unanswered calls in emergency call centers of power distribution companies, as this criterion records the specific requirements of how employee performance is shaped at emergency call centers of power distribution companies.

\section{Customer satisfaction}

Since this study is a survey at organizational level, customer satisfaction is a single criterion obtained from managers of emergency call centers of power distribution companies which is based on the data related to their customers' satisfaction, and was transformed into 5point Likert scale. This structure was modeled as a reflective factor. 


\section{Company performance}

In line with the studies by Aksin et al (2019) who suggested that the ultimate relationship in service-profit chain is represented by corporate earnings growth, this study measured performance in terms of percentages of decline or increase in sales amount during the last two years. This criterion is considered as a reflective structure. The variables are categorized and are used as indicators in order to indicate the strategy and the main type of call (input vs. output).

\section{Statistical population and sampling method}

The statistical population of the present study consists of 1100 employees of emergency department of power distribution companies. According to Krejcie \& Morgan (1970) table, minimum sample size for the present study was 285 people (Krejcie \& Morgan, 1970). In the present study, systematic sampling method was used for data collection. After distributing 350 questionnaires among the employees, 291 questionnaires were identified to be appropriate and the rest were excluded from analysis. (Table 2) shows demographic characteristics of the respondents.

\section{Table 2}

Demographic characteristics of respondents

\begin{tabular}{llll} 
Items & Description & Percentage & Number \\
\hline Gender & Female & 0 & 0 \\
& Male & $100 \%$ & 291 \\
\hline Age & Under 30 years old & $32 \%$ & 93 \\
& 31 to 40 years old & $40 \%$ & 116 \\
& 41 to 50 years old & $19 \%$ & 54 \\
& 51 years old and more & $9 \%$ & 28 \\
\hline Education & High school & $15 \%$ & 45 \\
& Associate degree & $20 \%$ & 58 \\
& Bachelor's degree & $56 \%$ & 163 \\
& Master's degree and PhD & $9 \%$ & 25
\end{tabular}

\section{Results}

In the present study, content and construct validity were used to assess validity of the questionnaire. In order to evaluate content validity of the questionnaire, experts' opinions in this field were used who were all university professors. Confirmatory factor analysis was also used to assess construct validity of the questionnaire. In order to examine the complex relationships related to human factors, which lead to customer satisfaction according to the literature, a sample of information was obtained at all emergency call centers of power 


\section{Evaluation of measurement model}

In order to evaluate whether the latent structures are continuously measured by observable variables or no, the convergence and differential validity were measured as shown in (Table 3). Convergence validity measures internal consistency for a given block of indices taking into account the level of composite reliability. Composite reliability is only applicable to reflective indices and, according to Nonali (2008) studies, this parameter should be greater than 0.7 .

(Table 3) shows that most of the latent variables in our model fulfill these requirements. Differential validity is assessed using average variance extracted (AVE) that is detectable only for reflective indices (Barclay et al., 1995) and must be greater than 0.5. This requirement is met by all the structures in the model. In addition, it has been suggested that a structure has good differential validity if its root mean square extracted for each structure is greater than the correlation between the structure and each type of structure in the model. As you can see in (Table 3), all the estimated structures in the model fulfill this condition, since each element in the matrix has the related diagnostic element. Therefore, differential validity of the estimated model is confirmed.

Table 3

Correlation matrix

\begin{tabular}{|c|c|c|c|c|c|c|c|c|c|}
\hline Variables & 1 & 2 & 3 & 4 & 5 & 6 & 7 & 8 & 9 \\
\hline $\begin{array}{l}\text { Human } \\
\text { resource } \\
\text { management }\end{array}$ & 1 & & & & & & & & \\
\hline Job plan & 0.63 & 1 & & & & & & & \\
\hline $\begin{array}{l}\text { Employee } \\
\text { satisfaction }\end{array}$ & 0.69 & 0.73 & 1 & & & & & & \\
\hline $\begin{array}{l}\text { Employee } \\
\text { efficiency }\end{array}$ & 0.53 & 0.43 & 0.52 & 1 & & & & & \\
\hline $\begin{array}{l}\text { Customer } \\
\text { satisfaction }\end{array}$ & 0.67 & 0.78 & 0.60 & 0.61 & 1 & & & & \\
\hline $\begin{array}{l}\text { Financial } \\
\text { performance }\end{array}$ & 0.53 & 0.61 & 0.68 & 0.62 & 0.58 & 1 & & & \\
\hline $\begin{array}{l}\text { Employee } \\
\text { retention }\end{array}$ & 0.44 & 0.72 & 0.50 & 0.74 & 0.48 & 0.48 & 1 & & \\
\hline Training & 0.63 & 0.52 & 0.45 & 0.70 & 0.70 & 0.49 & 0.63 & 1 & \\
\hline $\begin{array}{l}\text { Organizational } \\
\text { performance }\end{array}$ & 0.12 & 0.72 & 0.78 & 0.36 & 0.55 & 0.62 & 0.53 & 0.72 & 1 \\
\hline
\end{tabular}


It should be noted that the standard error level for examining the relationships is 0.05 and the confidence level is 0.95 . At $5 \%$ error level, the critical points in the normal curve are 1.96 and -1.96. If the significance coefficient of the regression test (T-VALUE coefficients) is greater than 1.96, the null hypothesis is rejected and the hypothesis is confirmed, and vice versa. In other words, in the normal curve, if the observed error level is within the range of 1.96 and 1.96, the null hypothesis and lack of a significant correlation between the variables is accepted, and if the observed error level exceeds the critical point of 1.96 and below the critical point of -1.96 , the hypothesis of existence of a significant relationship is accepted. (Table 4) below provides a better representation of the relationships and coefficients of the model parameters and significance of coefficients.

Table 4

Model estimation results and effectiveness of variables

\begin{tabular}{|c|c|c|c|c|}
\hline Independent variable & Dependent variable & Effect size & $\begin{array}{l}\text { Significan } \\
\text { ce } \\
\text { numbers }\end{array}$ & Hypothesis status \\
\hline $\begin{array}{l}\text { Human resource } \\
\text { management }\end{array}$ & Employee satisfaction & 0.047 & 5.050 & Confirmed \\
\hline Job plan & Employee satisfaction & .0067 & 10.207 & Confirmed \\
\hline Employee satisfaction & Employee retention & 0.105 & 14.550 & Confirmed \\
\hline \multirow[t]{2}{*}{ Employee efficiency } & Employee satisfaction & .0127 & 7.652 & Confirmed \\
\hline & Employee performance & 0.163 & 12.068 & Confirmed \\
\hline Customer satisfaction & Financial performance & 0.102 & 13.182 & Confirmed \\
\hline Employee retention & Customer satisfaction & 0.093 & 12.717 & Confirmed \\
\hline Training & Employee efficiency & 0.084 & 12.544 & Confirmed \\
\hline $\begin{array}{l}\text { Organizational } \\
\text { performance }\end{array}$ & Employee retention & 0.760 & 2.388 & \\
\hline
\end{tabular}

\section{Discussion}

The results in (Table 4) include path coefficient as well as the $t$ values obtained by bootstrap method in PLS. As suggested by Chain \& Marcolides (1994), the standardized path must be at least 0.20 in order to be significant. Both authority and job plan are significantly related to employee satisfaction, at significance level of $p<0.001$ and $p<0.01$, respectively. The effect of training on employee efficiency is also significant at $\mathrm{p}<0.001$ statistical level. Also, employee efficiency is significantly related to employee satisfaction at the significance level of $p<0.01$ and also related to employee performance at the significance level of $p<0.005$. All of these factors, namely employee satisfaction (at $\mathrm{p}<0.01$ level and t-statistic $=2.66$ ) as well as employee performance (at $\mathrm{p}<0.001$ level and t-statistic=2.81), lead to employee retention. Consequently, employee retention will also lead to customer satisfaction (at $\mathrm{P}<0.01$ 
significance level and t-statistic=2.69). Finally, customer satisfaction is significantly related to company outcomes (at $\mathrm{p}<0.005$ significance level and t-statistic=1.91).

The results of testing goodness of fit, in addition to estimating model coefficients and errors, presents a set of fit indices that using these indices the researcher can test the overall model and its fit. The fit indices of the model indicate that the model is in good conditions in terms of fit indices; since the ration of chi- 2 by degree of freedom $(\chi 2 / \mathrm{df})$ is equal to 1.79 which is less than the permissible value of 3, and RMSEA value is also equal to 0.043 and 0.074 which is less than the permissible value of 0.08 , so, there is no need for much reform. P-value is also equal to 0.000 which is less than 0.05 . And all the significance numbers related to the model parameters are greater than 1.96 and have become significant. The RMSEA value is equal to 0.000. The RMSEA permissible limit is 0.1. AGFI, GFI, and NFI indices are equal to 0.88 , 0.92 , and 0.88 , respectively, indicating a very good fit (Table 5).

\section{Table 4}

Fit indices of the research model

\begin{tabular}{lll}
\hline Index & Standard value & Values \\
\hline \multicolumn{1}{c}{$\boldsymbol{\chi}^{\mathbf{2}} / \mathbf{d f}$} & Lower than 3 & 1.94 \\
RMSEA & Lower than 0.1 & 0.000 \\
AGFI & Higher than 0.8 & 0.89 \\
GFI & Higher than 0.9 & 0.95 \\
NFI & Higher than 0.9 & 0.95 \\
\hline
\end{tabular}

In order to conduct this study, we examined employee-related paths that lead to customer satisfaction. In review of the literature, we investigated the factors involved in shaping customer satisfaction at emergency call centers of power distribution companies. We found that the specific order of employee-related factors on customer satisfaction has not yet been fully explored. In order to examine these complex relationships more closely, we first considered the presented models such as service-profit chain that has been previously tested in call centers in other areas (Chaiko et al., 2016). However, in fact, emergency call centers of power distribution companies did not exactly match this model, and there is a need to discover a more accurate system of these relationships. Therefore, the theory of structural approach was examined using structural equation methods the results of which are given below:

In the first block of relationships, the interactions between human resource policies and practices (job plan, authority, training, teamwork, etc.) and the most important outcomes in terms of employee satisfaction and efficiency were examined. These relationships were presented in the following way: employee satisfaction is not just the result of positive human resource practices. Some human resource practices such as job plan and job authority may result 
in employee satisfaction. Some other things such as training also lead to employee efficiency. In turn, employee efficiency is significantly related to employee satisfaction. Thus, our study shows that these relationships are relatively more complex than some of the other proposed models.

The next block of relationships is related to the factors that lead to employee retention. Once again, we point to more precise relationships that, through employee satisfaction, lead to encouraging employees to retain them in the company (a vital aspect of call center sector is characterized by high levels of job turnover); however, it does not necessarily encourage efficiency. Consequently, on the one hand, employee retention is a main indicator that mediates the relationship between employee satisfaction and customer satisfaction. On the other hand, employee retention mediates the relationship between employee efficiency and employee performance as well as customer satisfaction. The final relationship of the model shows that customer satisfaction leads to earnings growth in power distribution companies. This relationship was also observed in our study, although with limited power.

The contribution of this study is to inform researchers dealing with employee-customer interactions and need to examine the relationships between them. This is especially important for any subject that seeks to link human resources and marketing. In this section, we have discussed the main findings in this regard. Our study suggests that investing in employee training leads to customer satisfaction, but this relationship is not a simple linear relationship. What this study shows is that customer satisfaction is obtained as a result of employees' satisfaction with their jobs, and that satisfaction is also obtained as a result of investing in staff training and skill acquisition section. By investing in employee training, employee efficiency is directly affected, which in turn affects employee satisfaction. These findings are consistent with the primary studies by Porter \& Lalers (1968) who found that employee efficiency depends on employees' ability to perform their tasks satisfactorily.

Here, discussing AMO framework is useful which has been widely accepted in the literature of human resource management in order to explain the relationship between human resource practices and their performance. In this model, performance is a function of capacity/ability to do the job (in our study, obtained by training), the desire/motivation to do the job (satisfaction in our study), and the opportunity to do the job (in our study, authority and other features of job plan). Therefore, investing in human resource practices and especially in terms of training the employees helps them in performing their duties and results in higher employee satisfaction. These findings have important implications for management of emergency call centers of power distribution companies. One method in which employees can have more efficiency and therefore obtain more satisfaction is investing in employee training and development. And ultimately, this increases the level of customer satisfaction. This is consistent with previous studies saying that positive human resource practices improve the 
ability to provide high-quality services (Leith \& Diane, 2006), and that human resource practices based on employee training and evaluation improves service quality as well as customer satisfaction (Carrie \& Lyaon, 2008).

The major contribution of our study is to identify the weak relationship between customer satisfaction and financial performance of emergency call centers of power distribution companies. This is worthy of further consideration: first, in the case of call centers, the "hassle factor" involved in the complaint or change of service provider is important. Consequently, most customers, even those who are not satisfied, do not take any action. In other words, some customers are not loyal to the company because they are satisfied with the company but face with additional problems or costs when the service provider is changed. Therefore, customer satisfaction or dissatisfaction may not have a significant impact on financial performance of emergency call centers of power distribution companies. Second, in the area of call centers, it seems that employees often deal with angry and dissatisfied customers (Helms \& Mayo, 2009). In this regard, an alternative path for corporate growth and performance may lead to satisfactory customer management. Therefore, in call center sector, we may not expect strong levels of satisfaction among customers; however, focusing on minimizing their dissatisfaction is of great importance.

In terms of management practices, it should be noted that this study encourages us to consider a wide range of factors throughout the business process. In other words, the traditional separation of business practices may hinder the understanding that political decisions in human resources have serious consequences for marketing and vice versa. In this regard, we tend to develop more interdisciplinary models similar to the ones proposed by this study, to provide a more comprehensive view of the processes across the whole business. As a result, the sustainable growth experienced in retails and online services suggests that consumers are buying more and more online (per product category) daily. Consequently, we are increasingly facing customer support in online domain which is mainly done through call centers. This means that face-to-face business interactions between employees and customers by service encounters have been replaced by technology and online services. Therefore, customer satisfaction is increasingly dependent on virtual encounters through emergency call centers of power distribution companies which requires more knowledge and understanding of customer satisfaction in an environment that is usually accompanied by negative experiences rather than customer satisfaction. In fact, we still have relatively little information about human interaction in traditional offline environments versus technology-driven online environments. This knowledge is likely to change with our training in the area of online or telephone communications and development of new technologies

\section{Conclusion}


The present study aimed to investigate the relationship between human resource management, customer satisfaction, and job performance of employees of emergency call centers of power distribution companies. Organizations by human resources management of employees can benefit from its positive results in the organization. Organizations can engage in human resource management activities with employees. Organizations must ensure that all the organizational goals are properly defined and understood by the staff. They also need to provide the employees with awareness about their vital role in the organization and that survival of the organization depends on providing desirable services to customers by them. Organizations must provide their employees with sufficient resources to perform well; these resources include information, material resources, training, and employee development. In addition, organizations should provide a clear definition of reward for employees and explain them the relationship between employee good performance and the received rewards. These things cause that employees of organizations, especially employees of banks who perform repetitive tasks, enjoy doing a rich work and do their best in performing their assigned tasks, be committed to organizational goals, perform better, and provide customers with better quality services which will result in greater profitability for the organization.

\section{References}

Abdelatov, H., Maull, R., Smart, A. \& Baker, P. (2011). Customer satisfaction and service quality in UK financial services, Int. J. Oper Prod Manag, 27(9): 999-1019.

Abdolatov, D., Archer, T., Ghiabi, B. \& Moradi S. (2011), Waiting in vain: managing time and customer satisfaction at call centers. Psychology, 3(2): 213-216.

Aksin Z., Armony, M. \& Mehrotra, V. (2019). The modern call center: a multi-disciplinary perspective on operations management research. Prod, Oper, Manag, 16(6): 665-688.

Auckland-Dhaka, A. (2019). The impact of Call Center employees' customer orientation behaviours on service quality. J. Serv. Res, 10(3): 239-255.

Auxin, D., Valverde, M., Ryan, G. \& Batt R. (2016). The serviceprofit chain in call centre services. J. Serv, Theory Pract, 26(5): 616-641.

Bain, P., Tom A. \& Charles E. (2017). Operational challenges in the call center industry: a case study and resource-based framework. Manag, Serv, Qual, 16(5): 477-500.

Baradvaj, A. \& Ruggerion, R. (2008). Problematic customers and turnover intentions of customer service employees. J. Serv Mark, 26(7), 551-559.

Barclay, A., de Ruyter, K., Keen, C. \& Streukens S. (1995). Customer expectation dimensions of voice-to-voice service encounters: a scale-development study. Int. J. Serv. Ind. Manag, 11(2), 142-161.

Bennington, P., Watson, A., Mulvey, G. \& Taylor, P. (2018). Taylorism, targets and the pursuit of quantity and quality by call centre management. New Tech. Work Employ, 17(3): 170185.

Bharadwaj, N. \& Roggeveen, A. (2008). The impact of offshored and outsourced call service centers on customer appraisals. Mark Lett, 19(1): 13-23. 
Broadvaj, G. \& Rogun, C. (2008). Call centre management: responsibilities and performance. Int. J. Serv, Ind, Manag, 17(3): 284-300.

Brown, R. \& Maxell, S. (2002). An employment systems approach to turnover: human resources practices, quits, dismissals, and performance. Acad Manag J., 54(4): 695-717.

Butt, L. \& Kelvin, J. (2011). Customer satisfaction and call centers: an Australian study. Int. J. Serv. Ind Manag, 11(2), 162-173.

Carrie, M. \& Lyaon, C. (2008). The missing opportunity in organizational research: some implications for a theory of work performance. Acad Manag Rev, 7(4): 560-569.

Castilla, E. (2005). Social networks and employee performance in a call center. Am J. Sociol, 110(5): 1243-1283.

Chaiko, R., Hokama, L. \& Kadam, R. \& Kim I. (2016). Operational determinants of caller satisfaction in the banking/financial services call center. Int. J. Bank Mark, 20(4): 174180.

Chain, L. \& Marcolides, J. (1994). Putting the service-profit chain to work. Harv. Bus. Rev, 72(2): 164-174.

Chin, W. (2019). A partial least square latent variable modelling approach for measuring interaction effects: results from a Monte Carlo simulation study and an electronic-mail. Inform Syst, 14(2): 189-207.

Chong, V., Kumar, P. \& Tsiros, M. (2011). Attribute-level performance, satisfaction, and behavioral intentions over time: a consumption-system approach. J. Mark, 63(2), 88101.

Connell, T., Aksoy, L., Tor, W., Cooil, B. \& Wahren B. (2009). Call center satisfaction and customer retention in a co-branded service context. Manag Serv Qual, 16(3): 269-289.

Diane, F. \& Rani, M. (2009). The voice-to-technology (V2T) encounter and the call centre servicescape: navigation, spatiality and movement. J. Serv, Manag, 25(3): 349-368.

Diane, G. (2002). Customer Service in UK call centres: organisational perspectives and employee perceptions. J. Retail Consum Serv, 9(6): 309-316.

Dorna, M., Valverde, M. \& Ryan G. (2018). In search of job quality in call centers, Pers Rev, 38(3): 253-269.

Eric, A., Zeithaml, V., Berry, L. (2006). SERVQUAL: a multiple-item scale for measuring consumer perceptions of service quality. J. Retail, 64(1): 12-40.

Erigo, N. \& Pagani, N. (2008). High quality and low cost: the lean service centre. Eur. J. Mark, 43(11): 1477-1497.

Farsijani, H., Feizi, K. \& Shafiee N. (2011). The impact of competitive forces of organization on knowledge application to improve supply chain performance in automotive industry. Perspectives on Business Management, 39(6): 71-92.

Garcia, R., Davies, J., Keogh, B. \& Finnegan A. (2012). Customer orientated Six Sigma in call centre performance measurement. Int. J. Qual Reliab Manag, 26(6): 516-545.

Gilmour, A. \& Moreland, L. (2000). Call centres: how can service quality be managed? Irish Mark, 13(1): 3-11.

Harley, N. \& Stalemy, R. (2007). Lean transformation in the pure service environment: the case of the call service centre. Int. J. Oper Prod Manag, 29(1): 54-76.

Helms, L. \& Mayo, A. (2009). Customer-driven philosophy in the banking industry under different ownership status: the case of Greece. Serv Ind. J, 29(5), 607-620.

Jasmand, A., Mokhtar, S. \& Yusoff, R. (2012). The mediating effects of first call resolution on call centers' performance. J. Database Mark. Cust. Strategy Manag, 18(1): 16-30. 
Krejcie, C. \& Morgan, D. (1970). Customer satisfaction at a software support call center. Qual Prog, 33(1), 71-75.

Leith, Z. \& Diane, J. (2006). Australian call centres: time to search for a new management model? Int Employ Relat Rev, 15(1): 1-15.

Liu, L. (2010). Operationalizing service quality: providers' perspective. In: Proceedings for the Northeast Region Decision Sciences Institute, Northeast Decision Sciences Institute, 34(6): 533-538.

Macarm, E. (2009). ECSI customer satisfaction modelling and analysis: a case study. Total Qual. Manag Bus Excell, 18(5), 545-554.

Madren, S., Purcell, J. \& Kinnie, N. (2000). Evolving high commitment management and the experience of the RAC call centre. Hum Resour Manag J, 10(1): 63-78.

Mar, L. \& Parry, R. (2014). Managing customer services: human resource practices, quit rates, and sales growth. Acad Manag J, 4(3): 587-597.

McGuire, D. \& McLaren, L. (2009). The impact of physical environment on employee commitment in call centres: the mediating role of employee well-being. Team Perform Manag, 15(1), 35-48.

Misiak, Y. \& Demarias, J. (2011). The efficiency and quality dilemma: what drives South African call centre management performance indicators? S. Afr. J. Hum Resour Manag, 9(1): 55-71.

Moghaddami, M. \& Zare, M. (2008). Investigating Customer's Mental Image of Organization and Methods to Improve It; Third International Conference on Marketing Management, 39(2): 69-83.

Mukherjee, A. \& Malotra, E. (2006). Ambiguous professionalism: managing efficiency and service quality in an Israeli call centre. New Tech Work Employ, 22(1): 83-96.

Nonali, F. (2008). A study of strategic call center management: relationship between key performance indicators and customer satisfaction. Eur. J. Social Sci, 6(2): 268-276.

Paulson, E. \& Siditz, D. (2015). The partial least squares (PLS) approach to causal modeling: personal computer adoption and use as an illustration. Technol Stud, 2(2), 285-309.

Pierciand, R. A. (2009). Rethinking customer expectations of service quality: are call centers different? J. Serv Mark, 18(1): 60-78.

Porter, J. \& Lalers, P. (1968). Strategy and Human Resource Management. London: Palgrave Macmillan.

Powder, A. \& Madopalie, R. (2019). Operational determinants of caller satisfaction in the call center. Int. J. Serv. Ind. Manag, 11(2): 131-141.

Raffley, L. (2008). Workplace flexibility and job satisfaction: some evidence from Europe. Int. J. Manpower, 29(6): 539-566.

Raz, T. \& Blank, G. (2007). Customer dissatisfaction: the relationship between types of problems and customer response. Can J. Adm Sci, 13(3): 264-276.

Roberts, G. \& Pavlak, N. (1996). Disenchantment discontinuance in the diffusion of self-service technologies in the services industry: a case study in retail banking. J. Int Consum Mark, 7(2): 25-40.

Schalk, T. \& Van-Rikersel, J. (2007). Consumer responses to dissatisfaction with financial service providers: an exploration of why some stay while others switch. J. Financ Serv Mark, 8(4), 343-353.

Sergant, V. \& Frenkel, C. (2016). Generating sales while providing service: a study of customer service representatives' ambidextrous behavior. J. Mark, 76(1): 20-37. 
Seyyedi, Z. \& Akbari, Y. (2009). Call center outsourcing: coordinating staffing level and service quality. Manag Sci, 54(2): 369-383.

Shafiee-Nikabadi, M., Feizi, K., Olfat, L. \& Taghavifard, M. (2011). A Multidimensional Structure to Explain the Effect of Organizational Culture and Supply Chain Culture on Knowledge Transfer, Sharing, and Distribution in the Iranian Automotive Industry Supply Chain: with an Emphasis on Improving Supply Chain Performance. Scientific and Research Quarterly of Institute of Science and Information Technology of Iran, 25(1): 120-132.

Sharma, K., Mani, B., Kumar, S. \& Prabhakaran S. (2010). Influence of service quality on customer satisfaction application of Servqual model. Int. J. Bus. Manag, 5(4): 117-124.

Siavallino, A. \& Dahlgard, M. (2007). Benchmarking service quality performance at businessto-business and business-to-consumer call centers. J. Bus Ind Mark, 16(5), 340-353.

Tossend, A. (2007). Service quality in call centres: implications for customer loyalty. Manag Serv Qual, 12(6): 414-423.

Vog, S., Tam, M., Korczynski, M. \& Shire K. (2007). Beyond bureaucracy? Work organization in call centres. Int. J. Hum Resour Manag, 9(6): 957-979.

Walsh, H., Sharma, A. \& Prykop C. (2012). The role of the sales employee in securing customer satisfaction. Eur. J. Mark, 46(3): 489-508.

Wood, P., Naidoo, P. \& Lukea-Bhiwajee, S. (2006). Measuring service quality: perceptions of employees. Global J. Bus. Res, 4(1), 47-58.

Ziviar, B., Parry, S. \& Malhotra, N. (2012). Performance management in call centers: lessons, pitfalls and achievements in Fujitsu Services. Meas Bus Excell, 8(4): 55-62. 